\title{
Town-planning value of territory as the basis of the evaluation of zoning when conducting cadastral valuation of real estate
}

\author{
Anna Osennyaya ${ }^{1 *}$, Bella Khakhuk $^{1}$, Yuliya Sokolova ${ }^{1}$, and Nafset Husht ${ }^{1}$ \\ ${ }^{1}$ Department of Cadastre and Geoengineering, Kuban State Technological University, \\ 350011, Krasnodar, Russia, avosen2910@yandex.ru
}

\begin{abstract}
In modern Russian conditions, the correct determination of cadastral value is one of the most important tasks that stimulate the functioning, sustainable growth and development of the country's economy. Science-based mechanism of cadastral valuation will contribute to the building of stable economic relations between the state and society. Unjustified changes in cadastral value may have a negative impact on the budget of the municipality and the interests of the owners. In this connection, the determination of cadastral value on the basis of sciencebased methods and approaches is a priority; allowing revealing the potential and reserves of settlements, to carry out urban policy aimed at increasing the urban value of the territories. The available methodological basis does not fully explain the essence of price zoning, a number of significant factors of urban value of the territory, such as infrastructure and existing buildings, and, as a consequence, their impact on the algorithm for determining the cadastral value are missed. The use of General scientific methods, theoretical, economic and statistical analysis and modeling allowed clarifying the methodology of cadastral evaluation, taking into account the impact of zoning and urban value of the territories on the result of cadastral evaluation. The proposed model for calculating the urban value of the territory is based on the computer program developed by the authors, the use of which allows scientifically correct cadastral value of the estimated real estate and will contribute to a socially fair and "transparent" mechanism of taxation of real estate.
\end{abstract}

\section{Introduction}

According to the Russian legislation cadastral value is the basis for the calculation of land tax, tax on property of individuals and on the property of organizations, the sale and division of real estate, as well as for the calculation of payments under lease agreements of state (municipal) property. In this regard, the qualitative determination of the cadastral value of the Russian land becomes one of the most important conditions for the normal development and functioning of the national economy and the solution of the most important economic problems.

From the standpoint of economic sense $\square$ property tax should be determined on the basis of market value, as in fact it is a tax on wealth. But the determination of market value 
for all real estate is a complex and expensive procedure, so the cadastral value is used for taxation - the value is close enough, but not identical. The market value is determined individually, taking into account all the characteristics inherent in the estimated object, and cadastral is a normative-calculated value of real estate, without taking into account any features [1-5]. A comparison of cadastral and market values showed that the average difference between them is 30 per cent and in some cases 90 per cent, which is contrary to the legislation on the cadastral value of real property, which provides that if the market value differs from the cadastral value by less than 30 per cent, an evaluation report is sufficient to revise the cadastral value. And if more, it also requires an expert opinion confirming that the report is made without violations. That is, it can be argued that these $30 \%$ are just an acceptable range of deviations from the market cadastral value. At the same time, the opportunity provided to taxpayers to challenge the cadastral value was actively used. There were two waves of discontent: 1) citizens were dissatisfied with the fact of the appearance of taxes, and the need to challenge was regarded as an attack on their income and free time; 2) municipalities were dissatisfied with the fact that citizens through the courts and the Institute of contestation reduce tax revenues to the budget and thereby cross out existing financial plans [6-8]. According to the generalized information provided by GBU KK Kraytekhinventarizatsiy - Regional BTI, carrying out the state cadastral assessment in the Krasnodar territory, in the period from 1.12.2018 g. on 30.04.2009, as a result of consideration of appeals on correction of technical and (or) methodical errors made at determination of cadastral cost, the Commission on consideration of disputes on results of determination of cadastral cost in the territory of Krasnodar Krai made 572 decisions. Of these decisions on the recalculation of the cadastral value due to the presence of technical and (or) methodological errors made in determining the cadastral value -202 . Decisions to refuse to recalculate the cadastral value -371 . On the basis of 70 decisions on recalculation the cadastral cost of real estate objects was recalculated towards increase, on the basis of 132 decisions - towards decrease. At the same time, more than $92 \%$ of the claims were satisfied in court, that is, the vast majority. The intensity of emotions, discontent was and is the strongest, and the high percentage of contesting the results of cadastral evaluation indicate the imperfection of the existing evaluation mechanism. But does this mean that the problem lies only in the specific evaluators or only in the methodology?

In modern conditions the real estate is not only the land and permanent structures, and to a greater extent the integration of the evaluated object in the infrastructure of the settlement and the possibility of rational and economically viable use of the object person. Any built-up or to be built urban area at the time was a natural area with a certain level of value. However, as a result of anthropogenic, technogenic and other loads, there was a radical change in the quality characteristics, while, as a rule, the natural and environmental assessment decreased, but the level of social development increased. Urban value is a measure of the territory's ability to meet certain social requirements for its condition and use, which comprehensively reflects all the characteristics of a particular site acquired in the process of its development (location, availability of social, engineering and transport infrastructure, technical condition and historical and cultural value of the building, environmental and sanitary condition of the environment, protection from adverse technological and natural impacts and phenomena, aesthetic qualities of the landscape, etc.).

In modern conditions it is very important to create a quality living environment for a person with the least loss of value characteristics of the territory. It is necessary to carefully disclose the potential and reserves, to carry out such urban policy, which will increase the urban value of the territories, while increasing the market value [9-14]. 
The relevance of the use of urban zoning for cadastral evaluation at the present time is also that the optimal targeted use of the territory with an increase in its value potential can prevent a number of mistakes made recently in the illegal management of sealing construction and violation of urban planning standards, which reduces not only the quality of the living environment, but also the value characteristics of the territory. In addition, the town-planning zoning takes into account the legal aspect of the actual use of the territory (town-planning regulations). Objective trends in value characteristics are often in conflict with the market assessment of the territory, the level of which within the settlements is dictated by the factor of demand and consumer demand, while the territories with potentially high urban characteristics have low value. In addition, incorrect functional use over time further reduces it due to the deterioration of the environmental situation and aesthetic characteristics. Thus, urban value is a broader and more objective category than the concept of price that we are currently applying, which is influenced by market considerations.

To date, we see the need to improve the existing mechanism for calculating the cadastral value of real estate, namely, in terms of specifying the method of cadastral valuation of real estate, for which the real estate market is well developed, and, consequently, a comparative approach is a priority.

We believe that the method of cadastral valuation should take into account the impact on such segments of the real estate market as urban policy and approved by local governments urban planning documentation. To solve this issue, it is necessary to conduct research on the applicability of the model for determining the urban value of the territory in the calculation of the cadastral value of real estate.

\section{Materials and methods}

For calculation of the cadastral value have been selected within 8 cadastral districts of one of microdistricts of Krasnodar (Jubilee) plots three types of permitted use (hereinafter - the LIE). The study was the formation of a common list of land, located in cadastral blocks with numbers 23:43:0206020, 23:43:0206021, 23:43:0206043, 23:43:0206044, 23:43:0206029, 23:43:0206030, 23:43:0206045, 23:43:0206039 and confined streets: Kharkov, Minsk and Chekistov Prospekt electronic resource (PKK- public cadastral map).

Work on the calculation of the cadastral value of land in the study were carried out in the following order:

1. Primary grouping of real estate objects by VRI - segmentation (combining several objects with the same numeric VRI code);

2. Collection and analysis of information about the real estate market, as well as analysis of information not directly related to real estate, but affecting their value;

3. Collection of sufficient and reliable market information for each VRI (selection of objects-analogues);

4. Determination of factors of urban value of the territory and their values for each VRI;

5. Construction of the cadastral value assessment model for each formed group of real estate objects on the basis of the urban value model of the territory and the rationale for choosing the type of cadastral value assessment model;

6. Analysis of the quality of the cadastral value model;

7. Calculation of cadastral value, including individual calculations for real estate objects, for which it is impossible to perform the determination of cadastral value by mass valuation methods;

8. Analysis of the results of cadastral value determination. 
Due to the development of the selected segments of the real estate market in Krasnodar, as well as the sufficiency and representativeness of information on offers (transactions) with real estate in the calculation was used a comparative approach based on the comparison of prices of offers (transactions) for similar real estate. In order to build a model of the urban value of the territory, data on the cost of land plots of the studied territory with the following types of permitted use were collected:

- Garages;

- Individual housing construction;

- Public-business.

With the use of qualitative theoretical,economic and statistical analysis, a list of factors of urban value of the territory characterizing the selected segments of the real estate market was determined. All price-forming factors have been assigned the weights shown in table 1 according to the type of permitted use.

Table 1. Values of price-forming factors.

\begin{tabular}{|c|c|c|c|c|}
\hline \multirow{2}{*}{ № } & Factor of town-planning value & \multicolumn{3}{|c|}{ Weighting factor } \\
\cline { 3 - 5 } & $\begin{array}{c}\text { Individual } \\
\text { housing } \\
\text { construction }\end{array}$ & Garages & $\begin{array}{c}\text { Public- } \\
\text { business }\end{array}$ \\
\hline 1 & land plot area & 0.1 & 0.1 & 0.1 \\
\hline 2 & Compliance with permitted use & 0.1 & 0.1 & 0.1 \\
\hline 3 & $\begin{array}{c}\text { Location relative to roads (transport } \\
\text { accessibility) }\end{array}$ & 0.06 & 0.1 & 0.05 \\
\hline 4 & Proximity to recreational areas & 0.05 & 0.01 & 0.01 \\
\hline 5 & Degree of improvement & 0.12 & 0.05 & 0.07 \\
\hline 6 & $\begin{array}{c}\text { Proximity of pre-school and } \\
\text { educational institutions }\end{array}$ & 0.12 & 0.02 & 0.02 \\
\hline 7 & Proximity to major trade objects & 0.05 & 0.04 & 0.1 \\
\hline 8 & $\begin{array}{c}\text { Proximity to the cultural and } \\
\text { entertainment center }\end{array}$ & 0.05 & 0.05 & 0.1 \\
\hline 9 & $\begin{array}{c}\text { The proximity to the objects of } \\
\text { cultural and consumer services }\end{array}$ & 0.05 & 0.05 & 0.1 \\
\hline 10 & $\begin{array}{c}\text { The closeness to the catering } \\
\text { facilities }\end{array}$ & 0.05 & 0.05 & 0.05 \\
\hline 11 & $\begin{array}{c}\text { Proximity to the city center (the } \\
\text { center of the neighborhood) }\end{array}$ & 0.06 & 0.05 & 0.1 \\
\hline 12 & Proximity to guarded Parking lots & 0.03 & 0.3 & 0.1 \\
\hline 13 & $\begin{array}{c}\text { The proximity of the noise polluting } \\
\text { objects }\end{array}$ & 0.08 & 0.04 & 0.05 \\
\hline 14 & $\begin{array}{c}\text { The proximity of sources of } \\
\text { pollution }\end{array}$ & 0.08 & 0.04 & 0.05 \\
\hline & Subtotal & 1 & 1 & 1 \\
\hline
\end{tabular}

To determine the cadastral value based on the model of the urban values of the area used the computer program "Program for calculating the cadastral value of land" (Certificate of state registration of program for computer № 2019613907 from 26.03.2019 G.; holder: Federal state budget educational institution of higher professional education "Kuban state technological University" (FSBEI "Kuban state University"); authors: Pastukhov M. A., Shevchenko G., Gribkova I. S., Fall, A. V., Khakhuk B. A., Shishkin V. A) [15]. The development of a mathematical model of urban value using this software is based on the construction of a regression equation that establishes the relationship between the dependent variable (cadastral value) and the values of independent variables (priceforming factors of real estate). 
If it is impossible to include in the model of mass assessment of the cadastral value of all price-forming factors and subject to the availability of their values, adjustments are introduced. If there are individual differences that are not taken into account in the cadastral value model, appropriate adjustments are introduced [16-20].

Statistical model quality analysis includes checks:

- taking into account all price-forming factors for which the objects of comparison are different and the changes of which can affect the change in value;

- validity of signs at the coefficients of the statistical equation, their compliance with the nature of the influence of price-forming factors;

- compliance of the type of function of influence of each price-forming factor to the nature of such influence available in the real estate market;

- by Student's t-test;

- average approximation error;

- the coefficient of determination R2;

- by the calculated value of Fisher's F-test.

Indicators R2, F-Fisher criterion do not have an independent value, the requirements for them are met automatically when other requirements are met.

R2 ("R-square") - coefficient of determination. H.: R2 was 0.803 , or $80.3 \%$. So the calculated parameters of the model by $80.3 \%$ explain the relationship between the studied parameters. The higher the R2, the better the model used, the acceptable values should be greater than 0.8. If the analysis is incorrect, $\mathrm{R} 2$ values are in the range less than 0.5.

From the point of view of our research it is important to take into account that the chosen statistical model should be subject to the laws of pricing in the real estate market, and be balanced, that is, not to change significantly its results when removed from the processed sample of individual properties.

The regression model coefficients are calculated in the correlation and regression analysis of Excel using the correlation function on the basis of the obtained data on the market value of land offers of one type of permitted use. The result of the calculation is the specific indicator of cadastral value and cadastral value of each land plot.

\section{Results and discussions}

The analysis of the results of the cadastral value determination was carried out for each of the reviewed VRI separately.

We have selected 3 control land plots: with minimum, average and maximum cadastral value for each type of permitted use. For each land plot, an individual assessment of the market value was carried out using a comparative approach. The results were compared with those obtained by calculations of the cadastral value.

We have made an assumption about the sufficient quality of the calculation provided that the differences between the calculated cadastral value and the market value are not more than $15 \%$. If the difference is greater than $15 \%$, we suggest that the reasons for the deviation should be analysed and that we return to step 3 of the cadastral value calculation. Table 2 presents an analysis of the discrepancy between the cadastral value and the market value of the land plots.

Table 2. Analysis of the discrepancy between the cadastral value and the market value of land plots.

\begin{tabular}{|c|c|c|c|}
\hline \multirow{2}{*}{ Indicator } & \multicolumn{3}{|c|}{ Type of permitted use } \\
\cline { 2 - 4 } & Garages & $\begin{array}{c}\text { Individual housing } \\
\text { construction }\end{array}$ & Public-business \\
\hline $\begin{array}{c}\text { Maximum } \\
\text { cadastral value }\end{array}$ & 292739627.05 & 153416979.70 & 372319333.14 \\
\hline
\end{tabular}




\begin{tabular}{|c|c|c|c|}
\hline Market value & 299883047.69 & 156784464.90 & 322189505.70 \\
\hline Deviation, \% & $\mathbf{2 . 4 4}$ & $\mathbf{2 . 1 9}$ & $\mathbf{1 3 . 4 6}$ \\
\hline $\begin{array}{c}\text { Minimum } \\
\text { cadastral value }\end{array}$ & 150956.34 & 4472810.63 & 388734.25 \\
\hline Market value & 150748.08 & 4329055.64 & 354466.85 \\
\hline Deviation, \% & $\mathbf{0 . 1 4}$ & $\mathbf{3 . 2 1}$ & $\mathbf{8 . 8 2}$ \\
\hline $\begin{array}{c}\text { Average } \\
\text { cadastral value }\end{array}$ & 33029246.66 & 13804334.23 & 44316330.22 \\
\hline Market value & 33109028.40 & 12105046.73 & 49856212.40 \\
\hline Deviation, \% & $\mathbf{0 . 2 4}$ & $\mathbf{1 2 . 3 1}$ & $\mathbf{1 1 . 1 1}$ \\
\hline
\end{tabular}

The difference between cadastral value and market value is calculated using formula 1 :

$$
|(\mathrm{a}-\mathrm{b}) /[(\mathrm{a}+\mathrm{b}) / 2]| * 100 \% \text {, }
$$

where,

$\mathrm{a}=$ cadastral value, RUB

$\mathrm{b}=$ market value, RUB

Thus, the maximum deviations between the market and cadastral value are mainly observed for land plots with the type of permitted use of "Public-business" (13,46\%, 8,82\%, $11,11 \%$ ), what can be explained by the complexity of the selection - objects analogues to standard objects with this type of permitted use. For individual housing construction and garages, smaller values of deviations were revealed, which was achieved due to a larger number of analog objects and a more simplified as a result of this scheme of entering adjustments. However, there is a high difference (12.31\%) between the average cadastral value and the market value of the land plot with the type of permitted use of "Individual housing construction", which can be caused by inaccuracy of input and calculation of quality adjustments. Nevertheless, all the indicators of deviations for each type of permitted use are within the tolerance (15\%), which indicates a sufficiently high level of quality of the cadastral value calculation based on the model of urban value of the territory.

Of particular scientific interest is the analysis of the applicability of the proposed method of determining the cadastral value for the remaining VRI land plots, as well as for the main groups of capital construction projects, which will build a sound mathematical mechanism for calculating the cadastral value within the existing method of cadastral valuation of real estate.

\section{Conclusion}

For land plots with the selected types of permitted use, the previously stated hypothesis about the possibility of using the proposed model for determining the urban value of the territory for calculating the cadastral value of real estate objects grouped by segments of the real estate market with sufficient representativeness of information on transactions in conditions of sufficient activity of the real estate market was confirmed.

We have proposed a list of the main pricing factors and their weight coefficients in relation to the three types of permitted use, which can be taken as the basis for determining the zones of urban value not only for calculating the cadastral value of land, but also a significant part of capital construction projects.

A computer program for calculating the cadastral value of real estate is proposed and tested using a mathematical model for determining the urban value of the territory, based on the construction of a regression equation that establishes the relationship between the dependent variable (cadastral value) and the values of independent variables (price-forming factors of real estate). 


\section{References}

1. Federal law of Russian Federation of 03.07.2016 No. 237

2. Federal law of Russian Federation of 12.05.2017 No. 226

3. A.V. Osennyaya, A.M. Seredin, I.V. Budagov, B.A. Khakhuk, L.K. Anisimova, A.A. Kush, D.A. Gura, M.A. Pastukhov, Cadastral valuation as the basis of real estate taxation (Krasnodar, 2017)

4. A.V. Osennyaya, I.S. Gribkova, M.A. Pastukhovs, The real estate Cadastre (Krasnodar, 2015)

5. A.V. Osennyaya, I.V. Budagov, B.A. Khakhuk, N.O. Khashpakiants, V.V. Chemodurov, Economics of construction and urban development 2 (2017)

6. Interregional public organization for the promotion of the market of geoinformation technologies and services "GIS Association", http://www.gisa.ru/38040.html

7. A.V. Kaminsky, Economic strategy 3 (2016)

8. A.V. Kaminsky, Property relations in the Russian Federation 2 (2016)

9. Federal Land Cadastre Service of Russia Land (Real Estate) Mass Valuation Systems for Taxation Purposes in Europe (Federal Land Cadastre Service of Russia, Moscow, 2001)

10. J. Woltier, E. Alexander, M. Ruth, Place-Based Evaluation for Integrated Land-Use Management (Routledge, Maryland, 2015)

11. A.V. Osennyaya, I.S. Gribkova, Theoretical foundations of the cadastre of built-up areas (Krasnodar, 2012)

12. A.V. Osennyaya, E.D. Osennyaya, B.A. Khakhuk, Bulletin of the Adyghe state University, Series 5, Economics 4 (2016)

13. A.V. Osennyaya, I.V. Budagov, B.A. Khakhu, Modern studies of the main directions of Humanities and natural Sciences: materials of the international scientific practical conference (2017)

14. A.V. Osennyaya, I.V Budagov, B.A. Khakhuk, A.A. Kushu, Bulletin of the Adyghe state University, Series 5, Economics (2017)

15. Program for calculating the cadastral value of land, Certificate of state registration of computer programs № 2019613907 (FGBOU IN "KubSTU», 2019)

16. M.I. Sidorenko, A.V. Osennyaya, Nauka. Technique. Technologies, Polytechnic Bulletin 2 (2015)

17. A.V. Osennyaya, I.S. Gribkova, M.A. Pastukhov, Real estate Cadastre, Textbook (Krasnodar, 2015)

18. A.V. Osennyaya, B.A. Khakhuk, A.A. Kusha., A.A. Kolomytseva, Part I, Problems of regional economy $\mathbf{3}$ (2018)

19. A.V. Osennyaya, B.A. Khakhuk, A.A. Kolomytseva, Part II, Problems of regional economy 3 (2018)

20. A. V. Osennyaya, B. A. Hahuk, A. A. Kolomytseva, Part III, Problems of regional economy 4 (2018) 